\title{
Tworzenie (się) laboratorium. Humanistyka wobec materialności narzędzi i przedmiotów badania'
}

Dariusz Brzostek

TEKSTY DRUGIE 2021, NR 2, S. 153-163

DOI: 10.18318/td.2021.2.9 | ORCID: 0000-0001-8094-5159

K lopot akademickiej humanistyki z laboratorium najłatwiej opisać za pomocą napięcia, jakie rodzi się między metaforą a konkretem. Publikacje humanistów pełne są bowiem laboratoryjnych metafor odnoszących się zarówno do procesu twórczego („sztuka jako eksperyment"), jak i do charakterystyki postępowania badawczego („tekst jako laboratorium idei”). Kiedy jednak stawką w grze staje się praca laboratoryjna traktowana dosłownie, a zatem "praca w laboratorium" czy też "praca z laboratorium" - postrzeganym jako "miejsce pracy i zestaw sił produkcyjnych, które umożliwiają konstruowanie rzeczywistości”2, wówczas humanistyka akademicka przyjmuje zwykle postawę dość defensywną, naznaczoną pewną dozą nieufności

1 Recenzja książki: P. Marecki Praktyka i eksperyment. Laboratoryjny model humanistyki, Wydawnictwo UJ, Kraków 2019.

2 B. Latour, S. Woolgar Życie laboratoryjne. Konstruowanie faktów naukowych, przeł. K. Abriszewski i in., Narodowe Centrum Kultury, Warszawa 2020, s. 321.
Dariusz Brzostek -

dr hab., prof. UMK, dyrektor Instytutu Nauk o Kulturze UMK. Ostatnio opublikował: Gameplay, Emotions and Narrative. Independent Games Experienced (Pittsburgh 2019; z Katarzyną Maraki Miłoszem Markockim) oraz Wola nie-wiedzy. Horror postmodernistyczny

czy groza ponowoczesności? (Toruń 2020). 
wobec materialności narzędzi badawczych oraz technologii umożliwiających ich tworzenie. W tym kontekście książka Piotra Mareckiego, podejmująca temat „laboratoryjnego modelu humanistyki” ma w polskim piśmiennictwie charakter wyjątkowy, gdyż jej autor deklaruje wprost, że nie jest ona „kolejnym głosem teoretycznym w zakresie wiedzy o laboratoriach, ale elementem praktykowania samego laboratorium, notesem wizyt w nim, pracy w grupie z osobami reprezentującymi różne dyscypliny (programistami, artystami, praktykami), pracy ze sprzętem (często bardzo unikalnym)"3. Praktyka i eksperyment jest zarazem zapisem procesu projektowania i konstruowania konkretnego laboratorium humanistycznego - „UBU lab” na Uniwersytecie Jagiellońskim w latach 2016-2019 - jako „koniecznego narzędzia do badań nad kulturą cyfrową"4, a w tym szczególnym przypadku „modeli ekspresji cyfrowej w Polsce i Europie Środkowo-Wschodniej"s. Autor opisuje zatem dokładnie narzędzia, przestrzeń i zespół, a także metody, etapy tworzenia, problemy organizacyjne i praktyki użytkowania labu, jakie wyłaniały się stopniowo wraz z krystalizowaniem się tej jednostki badawczej. Jest to niewątpliwy walor książki, która staje się w ten sposób na poły pracą etnograficzną, na poły zaś vademecum dla badaczy, którzy pragnęliby podążać w nowej humanistyce wyboistą ścieżką pracy laboratoryjnej. Marecki świadomie unika przy tym typowego dla humanistów teoretyzowania, mającego na celu budowanie modelu pracy laboratoryjnej, zaznaczając już na wstępie, że nie zamierza traktować „samego tekstu [...] jako laboratorium"6. I jest to zastrzeżenie ze wszech miar słuszne, takie ujęcie sprowadzałoby bowiem całą sferę praktyk laboratoryjnych raczej do słów (na temat owych praktyk wypowiedzianych) niż do rzeczy - narzędzi i przedmiotów badania, ujmowanych w ich materialności: działaniu i oddziaływaniu na ludzkich aktorów oraz ich poczynania. A zatem u Mareckiego to nie tekst staje się laboratorium. Czy jednak oznacza to, że samo laboratorium staje się tekstem? Czy ceną za uniknięcie pułapki słów i modeli teoretycznych staje się tekstualizacja samego laboratorium, które zmienia się w zestaw znaków do (od)czytania? Poniżej spróbuję przybliżyć tak sformułowaną perspektywę poznawczą.

5 Tamże, s. 57.

6 Tamże, s. 8. 
Samoświadomość badacza "praktykującego laboratorium", który „popełnia błędy, eksperymentuje, wycofuje się z pewnych decyzji i dokumentuje ten proces"', jest istotnym i cennym składnikiem relacji zawartej w Laboratoryjnym modelu humanistyki. Autor starannie unika przy tym uogólniającej perspektywy: „Jak buduje się laboratorium humanistyczne”, by skupić się na jednostkowym doświadczeniu: „Jak budowaliśmy UBU lab”, co czyni omawianą książkę wartościowym zapisem tworzenia (się) warsztatu pracy konkretnych badaczy zgłębiających określony, wyraźnie zdefiniowany problem badawczy. W tym wymiarze monografia Mareckiego - właśnie jako studium przypadku - bliższa jest terenowej praktyce etnograficznej z jej zakorzenieniem w przygodnym „tu i teraz" niż ujęciom archeologicznym, historycznym czy teoretycznym, preferującym szerszą skalę i głębszą perspektywę czasową w analizie obserwowanych zjawisk. Trafnie pisze o tym sam autor: „Nie myślałem o badaniach prowadzonych w labie w kategoriach obiektywnych. Byłem także świadom, że badania mediów cyfrowych w kontekście lokalnym uwikłane są w sieć dyskursów rozpiętych między teraźniejszością a przeszłością, w tym dyskursów «inaczej» konstruujących patrzenie na media, i że pracując w labie, nie ustalimy uniwersalnych prawd, ale nieustannie będziemy potwierdzać tezy w konkretnych artefaktach, osobliwościach, mikrohistoriach"8.

Ponieważ książka Piotra Mareckiego, przynosząca m.in. antropologię społeczną pracy laboratoryjnej, ma zarazem charakter autoetnograficzny i odwołuje się do jego własnych doświadczeń i praktyk jako organizatora „UBU lab”, pozwolę sobie odnieść się do zawartych w niej obserwacji i wniosków z perspektywy mojej pracy badawczej, która niejednokrotnie, czasami intencjonalnie, a niekiedy z konieczności, przybierała kształt laboratoryjny i przebiegała w środowiskach - proszę wybaczyć mi to niezręczne sformułowanie, ale jest ono w tym miejscu nieodzowne - labopodobnych. Nazywam je w taki właśnie sposób, aby podkreślić, że humanista stosunkowo rzadko ma sposobność i możliwość działać w warunkach laboratoryjnych, czyli w przestrzeniach i zespołach powołanych do istnienia i skonstruowanych celowo jako laboratoria, co nie oznacza bynajmniej, że nie zdarza mu się prowadzić badań, które takich właśnie warunków wymagają. Owocuje to koniecznością wypracowywania „humanistycznych praktyk laboratoryjnych" ad hoc - jako reakcji na niedomagania systemu

7 Tamże.

8 Tamże, s. 18. 
nauki, niewiążącego zazwyczaj zajęć laboratoryjnych z humanistyką. Marecki posługuje się w swej książce wyrazistym i retorycznie skutecznym przykładem platform studies oraz badań kulturowych nad technologiami cyfrowymi, ale jego obserwacje można z powodzeniem zastosować także do innych obszarów badawczych - uzupełniając je przy okazji o spostrzeżenia dotyczące praktyk związanych z innymi niż cyfrowe typami tekstów kultury.

Moje własne obserwacje i wnioski wynikają wprost z doświadczeń pracy badawczej w zakresie sound studies, których związek z technologią (zarówno cyfrową, jak i analogową) jest dość oczywisty, wszak skupiają się one na reprodukcji dźwięku, jego mediach i nośnikach materialnych. Niemniej podobne wrażenia towarzyszyły mi również w badaniach tekstów zaliczanych do tzw. poezji dźwiękowej, i to nawet wówczas, gdy starałem się skupiać raczej na właściwych jej formach ekspresji artystycznej niż na swoistości tworzywa użytego do przechowywania takich komunikatów artystycznych. Omówię tu pokrótce te właśnie doświadczenia, aby następnie sformułować kilka wniosków i propozycji teoretycznych wartych, w moim przekonaniu, dalszej dyskusji i refleksji. Badania nad dźwiękiem, jego reprodukcją oraz mediami zakładają implicite pracę w zespołach, środowiskach i przestrzeniach, które z czasem, nierzadko z konieczności lub mimochodem, okazują się lub stają laboratoriami, gromadząc ludzi i sprzęt, publikacje, artefakty i gadżety, narracje, praktyki, kompetencje i doświadczenia związane z określonymi technologiami i/lub nośnikami - splecione w sieć zależności i oddziaływań w niezinstytucjonalizowanej przestrzeni. Każdy badacz gromadzi zatem już od początku swych studiów swoistą kolekcję: nagrań i ich materialnych nośników, urządzeń umożliwiających odsłuch zebranego materiału etc., i czyni to, nawet jeśli nie dysponuje oficjalnie wyodrębnioną przestrzenią umożliwiającą mu organizowanie laboratorium i jego funkcjonowania (czasu, stanowisk, funduszy). Dzieje się tak, gdyż w obszarze sound studies bezpośredni dostęp do analizowanych technologii, mediów i nagrań jest nie tylko koniecznym, lecz także wstępnym warunkiem rozpoczęcia badań, niezależnie od tego, czy uwagę poświęca się samym nośnikom, zawartym na nich tekstom kultury czy praktykom użytkowników (twórców, producentów, odbiorców). By zilustrować opisany powyżej proces „tworzenia (się) laboratorium" wokół wybranego przedmiotu badań, przywołam kilka przykładów odnoszących się do moich własnych zainteresowań naukowych, które wymusiły na piszącym te słowa przyjęcie trybu pracy laboratoryjnej poza 
instytucjonalnym „labem", a więc w laboratorium tworzonym ad hoc w warunkach domowych lub "gabinetowych". Były to m.in.:

- badania poświęcone praktykom audiofilów i kolekcjonerów sprzętu oraz nagrań;

- studia nad tworzeniem archiwów i kolekcji dźwiękowych (muzycznych, dokumentalnych, użytkowych etc.), w tym historii rejestrowania pejzaży dźwiękowych i zapisów bioakustycznych, okazujących się nie tyle akustycznymi reprezentacjami natury, ile zmediatyzowanymi hybrydami tejże natury oraz technologii umożliwiającej nagranie dźwięku;

- opis praktyk twórczych inżynierów dźwięku i realizatorów nagrań w różnych lokalnych środowiskach kulturowych (PRL, Jamajka) warunkujących tryb pracy determinowanej przez możliwości i ograniczenia dostępnych technologii";

- analiza funkcjonowania technologicznych hybryd w postaci sound systemów służących do rejestracji, reprodukcji i odtwarzania dźwięku za pomocą nośników analogowych i cyfrowych pracujących wspólnie, a zatem oddziałujących na siebie i korygujących swoje działanie;

- przegląd cyfrowych symulacji dawnego sprzętu analogowego - funkcjonujących w środowisku cyfrowym i wytwarzających symulakry analogowych brzmień i form zapisu dźwięku, wykorzystywane np. w estetyce retrofuturystycznej ${ }^{10}$.

We wszystkich tych przypadkach niezbędna okazywała się praca laboratoryjna: porównywanie dostępnych nagrań, szczegółowa obserwacja sposobów użytkowania sprzętu w jego macierzystym środowisku (np. studiu nagraniowym lub radiowym), etnograficzny opis praktyk użytkowników (zawierający elementy obserwacji uczestniczącej), wizyty studyjne, a także moje własne zbiory, kompetencje i doświadczenia pozaakademickie, nabyte podczas pracy przy edycji i produkcji dźwięku (w tym wydawnictw

9 Warto tu podkreślić, że studia nagraniowe bardzo często przyjmują postać laboratoriów dźwiękowych. Pisałem o tym w tekstach: The Polish Radio Experimental Studio as a laboratory, w: Ultra sounds: the sonic art of Polish Radio Experimental Studio, ed. by D. Crowley, Kehrer Verlag, Heidelberg 2019, s. 50-71 [współautorka: Joanna Walewska]; Electronic music, socialism and modernity: on remastering the Archives of the Polish Radio Experimental Studio, w: Transcultural music traditions: global participation and regional diversity in the Modern Age, ed. by R. Strohm, Verlag für Wissenschaft und Bildung, Berlin 2020, s. 329-340.

10 Zob. D. Brzostek The sonoristic triangle, Or, what Claude Lévi-Strauss would have said about the sound culture if he hd not talked about cooking instead, "AVANT. Trends in Interdisciplinary Studies" 2017 vol. 7: Situating Art and Cognition, s. 93-100. 
muzycznych i dokumentalnych). Zarazem wszystkie te działania były prowadzone poza instytucjonalną przestrzenią „laboratorium dźwiękowego", którą nie dysponowałem oficjalnie, lecz konstruowałem okazjonalnie na potrzeby kolejnych projektów.

Jak jednak zauważyłem powyżej, w odniesieniu do sound studies ów związek przedmiotu obserwacji z technologią i materialnością nośnika jest dość oczywisty, a zatem badacz wkraczający na to terytorium zazwyczaj już na wstępie doskonale zdaje sobie sprawę, że jego praca będzie miała charakter częściowo warsztatowy, a po części laboratoryjny - obejmując wizyty studyjne, gromadzenie, katalogowanie i porównywanie mediów etc. Dużo mniej oczywiste są te przypadki, w których badacz np. różnych form artystycznych zostaje okazjonalnie uwikłany w konieczność pracy laboratoryjnej, wymuszonej nań przez specyfikę badanych tekstów, a mówiąc dokładniej - sposobu ich archiwizowania i udostępniania. Mam tu na myśli wszystkich humanistów sięgających (z wyboru lub konieczności) po zbiory tekstów kolekcjonowanych przez lata na nośnikach dziś już niefunkcjonujących w głównym obiegu, często zaś w ogóle nieprodukowanych i sporadycznie tylko serwisowanych (płyty szelakowe $78 \mathrm{rpm}$, taśmy magnetyczne, kasety magnetofonowe, minidyski MD, kasety VHS i Mini DV itp.).W moim wypadku wynikało to z badań prowadzonych nad poezją dźwiękową oraz związkami technik reprodukcji dźwięku z muzyką konkretną. Przywołam tu jeden tylko przykład, by zilustrować konstytuowanie się nieintencjonalnej przestrzeni laboratoryjnej wokół niektórych przedmiotów refleksji humanistycznej. Podczas stażu badawczego w Centre International de Poésie: Marseille -ośrodku dysponującym unikatowymi zbiorami poezji dźwiękowej (szczególnie z dorobku Henriego Chopina" ${ }^{11}$ i innych autorów francuskich) - uzyskałem dostęp do dużego zasobu dzieł zgromadzonych na nośnikach właściwych dla sposobu pracy poszczególnych twórców oraz czasów, w których dokumentowano działania konkretnych autorów. W związku z tym okazało się, że ogromna większość kolekcji jest przechowywana na oryginalnych nośnikach, takich jak taśmy magnetofonowe (standardowe, o szerokości 1/4 cala), kasety magnetofonowe i płyty winylowe (szczególnie w przypadku Chopinowskiego periodyku „Revue OU” z lat 1967-1974).

11 Warto podkreślić w tym miejscu, że Chopin przez całe życie korzystał niemal wyłącznie z tradycyjnych magnetofonów szpulowych, których właściwości (techniczne, brzmieniowe etc.) stanowiły podstawę jego pracy twórczej, tak jak taśma magnetyczna zapewniała fundament ontologiczny jego tekstom poetyckim. 
Niezbędne do odtwarzania oryginalnych nagrań urządzenia (magnetofony szpulowe i kasetowe, gramofony) wymagają nie tylko stałego serwisowania, które z czasem staje się coraz bardziej kłopotliwe z powodu braku części zamiennych, lecz także odpowiednich dla przestrzeni archiwalno-bibliotecznej warunków użytkowania: stanowisk z dostępnymi słuchawkami etc. W praktyce jednak mogło się okazać, że w czytelni dostępne są tylko magnetofony kasetowe, nie wszystkie z nich pozostają sprawne i w zasadzie nie są poddawane przeglądom technicznym (co może mieć wpływ np. na zanieczyszczenie głowicy odczytującej lub prędkość przesuwu taśmy). Sprawiało to, że część kolekcji była wyłączona z obiegu, a badacz stawał bezradny w obliczu anachronicznego medium, wymuszającego na archiwistach próbę odtworzenia środowiska technologicznego, w którym możliwe było jego sprawne funkcjonowanie. Sięgam po ten właśnie przykład, gdyż jest on niezwykle charakterystyczny oraz wymowny. Twórcy poezji dźwiękowej chętnie czerpali bowiem inspirację z technologicznych właściwości taśmy magnetycznej, eksponując w swoich kompozycjach właśnie materialność nośnika, który stawał się zarówno medium przekazu, jak i jego tworzywem. W tym wypadku zatem jesteśmy bardzo blisko konstatacji Mareckiego, gdy podkreśla on konieczność odtwarzania tekstów kultury cyfrowej we właściwym im środowisku technologicznym ${ }^{12}$, które w tym celu należy odtworzyć: skompletować, nierzadko odrestaurować i regularnie serwisować. Oczywiście sytuacja opisana powyżej nie dotyczy wyłącznie badaczy poezji dźwiękowej, ale równie często staje się udziałem etnologów, etnomuzykologów czy folklorystów - poszukując nie tyle konkretnych mediów, ile tekstów kultury (pieśni, opowieści, wspomnień czy wywiadów) z czasów „przedcyfrowych”, są oni zmuszeni konstruować laboratoria umożliwiające dostęp do zachowanych zbiorów, ich lekturę, analizę, a nawet digitalizację i upowszechnienie.

Wszystkie te sytuacje, wyzwania i problemy badawcze stają się oczywiście również udziałem badaczy kultury elektronicznej, którzy próbują „profesjonalnie zajmować się dziełami sztuki cyfrowej”"13, badać strategie i praktyki użytkowników mediów elektronicznych ${ }^{14}$, a przede wszystkim "gromadzić komputery osobiste istotne dla modeli ekspresji cyfrowej

12 Marecki pisze wprost, że jednym z głównych zadań powołanego przez niego labu jest umożliwienie: „uruchamiania dzieła cyfrowego z platformy natywnej, czyli tej, na którą dany utwór został napisany". P. Marecki Praktyka i eksperyment, s. 41.

13 Tamże, s. 41. 
w Polsce i Europie Środkowo-Wschodniej"15 w UBU lab. Marecki skrzętnie to odnotowuje, skupiając się kolejno na kompletowaniu artefaktów i narzędzi, organizowaniu przestrzeni i tworzeniu zespołu badawczego. W tym właśnie miejscu, w ostatnim rozdziale książki, wyłania się swoisty model tworzenia (się) laboratorium wywiedziony wprost z praktyki: kolekcjonowania, restaurowania, obserwowania i używania zebranych narzędzi. Staje się on zarazem częścią wspólną działań wszystkich humanistów pracujących z laboratoriami, niezależnie od tego, czy odtwarzają one lokalną kulturę cyfrową, wizualną czy audialną wraz z jej mediami, artefaktami i tekstami. Istotnym aspektem owej części wspólnej jest także podkreślany wielokrotnie przez autora Praktyki i eksperymentu twórczy potencjał humanistycznych laboratoriów służących m.in. jako „platformy do produkcji dzieł artystycznych"16, niezależnie od tego, czy będzie to poezja cyfrowa, sound art czy sztuka wideo. Estetyzacja doświadczenia laboratoryjnego nie jest wszak celem prac badawczych podejmowanych poza humanistyką. Jest w książce Mareckiego jeszcze jeden wątek, na który warto w tym kontekście zwrócić uwagę. Wiąże się on bezpośrednio z kategorią lokalności, dotyczącą zarówno samej pracy laboratoryjnej, jak i obszaru badań objętych tą pracą. Autor Praktyki i eksperymentu podkreśla wielokrotnie, że jego celem było „założenie labu w Polsce i chęć zajęcia się lokalną kulturą cyfrową"17 oraz stworzenie narzędzia do „konstruowania narracji wskazującej różnice między Zachodem a Wschodem, oryginalnością a kopią, platformą zamkniętą a otwartą i modyfikowaną" ${ }^{\prime 18}$. Te ambitne w założeniu i precyzyjnie sformułowane postulaty badawcze skłaniają jednak do postawienia kilku pytań, na które Marecki odpowiada raczej połowicznie i tylko mimochodem. Problem kluczowy dotyczy bowiem samej kategorii lokalności kultury badanej „w” i „za pośrednictwem" laboratorium - jej praktyk, wytworów materialnych i narracji. Otóż środkowoeuropejska demoscena (albo środkowoeuropejski "trzeci obieg" kaset magnetofonowych) zostają w pewnym stopniu odtworzone w, również środkowoeuropejskim, laboratorium - będącym zarazem konkretnym miejscem pracy i konstruowania wiedzy za pomocą określonych praktyk. Czy jednak środowisko to ma odtwarzać warunki funkcjonowania

\footnotetext{
15 Tamże, s. 57.

16 Tamże, s. 28.

17 Tamże, s. 47.

18 Tamże, s. 16.
} 
lokalnej kultury poddanej obserwacji (wraz z jej ograniczeniami, niedogodnościami etc.), czy też raczej stworzyć optymalne warunki pracy dla badaczy tej kultury? Zdaję sobie oczywiście sprawę, że jedno bynajmniej nie musi wykluczać drugiego, niemniej pytanie to pozostaje otwarte i implikuje kolejne: Co dzieje się w tak pomyślanym laboratorium? Odtwarza się w nim warunki i reprodukuje praktyki dawnych użytkowników sprzętu elektronicznego czy (re)konstruuje praktyki badawcze obserwatorów (np. podpatrzone w innych laboratoriach o podobnym profilu)? Czy jedne niepostrzeżenie przekształcają się w drugie, wzbogacone po prostu o teoretyczną świadomość obserwowania własnych działań? I w konsekwencji: Czy samo tworzenie (się) labu, proces tak starannie opisany przez Mareckiego, jest odtworzeniem kontekstu macierzystego? Czy lab nie wymaga jednak osobnego badania etnograficznego jako lokalne środowisko (pracy) zajmujące się reprodukcją innych, dawnych i niebadawczych środowisk lokalnych? Sądzę, że te kwestie zasługują na pogłębioną refleksję, i uważam również, że istotnym jej składnikiem powinna się stać analiza napięcia między projektowaniem i konstruowaniem laboratorium jako miejsca pracy badawczej a tworzeniem (się) laboratorium jako środowiska, w którym humaniści muszą sobie radzić z zastanym materiałem badawczym poza zinstytucjonalizowaną przestrzenią obserwacji i analizy danych (tekstów kultury, jej artefaktów etc.).

Aby podsumować przedstawione powyżej obserwacje, chciałbym w tym miejscu, korzystając ze szczegółowego i wnikliwego opisu dostarczonego przez Piotra Mareckiego oraz własnych doświadczeń „laboratoryjnych”, ująć ostatecznie laboratorium (humanistyczne) jako system autopoietyczny ${ }^{19}$, przede wszystkim w celu uchwycenia pewnego praktycznego aspektu konstruowania tego narzędzia poznawczego humanistyki, wynikającego z nieuniknionego napięcia między projektowaniem "labu" i tworzeniem (się) „labu”, które mogą być postrzegane zarówno jako antagonistyczne siły wpływające na jego ostateczny kształt, jak i kolejne fazy jednego procesu twórczego. W tym ujęciu samo laboratorium jawi się więc jako system określany przez wewnętrzne interakcje między jego elementami (czynnikami ludzkimi i pozaludzkimi - w świetle teorii aktora-sieci), a także nieustannie reagujący na zmieniające się warunki zewnętrzne (determinowane przez zinstytucjonalizowane decyzje uczelni i grantodawców, rynek sprzętu i usług

19 Warunki określające istnienie takiego systemu sformułowali przed laty Humberto R. Maturana i Francisco J. Varela w pracy Autopoiesis and cognition: the realization of the living, D. Reidel Publishing Company, Dordrecht-Boston-London 1980, s. 9-11. 
specjalistycznych itp. $)^{20}$. Lab jako system autopoietyczny nie tylko podtrzymuje i rozwija swoje istnienie, lecz także tworzy aktorów zaangażowanych w jego funkcjonowanie, determinując ich praktyki i wymuszając nabywanie określonych kompetencji (administracyjnych, technicznych, badawczych etc.). Tworzeniu (się) laboratorium towarzyszyć zatem musi, szczególnie w przypadku humanisty wykonującego pracę laboratoryjną, równoległy proces „stawania-się-laborantem”, który jest, by sparafrazować tu znaną definicję konstruowania podmiotowości posthumanistycznej sformułowaną przez Rosi Braidotti, ,procesem redefiniowania własnego poczucia osadzenia w podzielanym świecie i powiązania z nim"21. Czy zatem humanista w trakcie swojego „stawania-się-laborantem” zarazem w sposób nieunikniony „staje-się-posthumanistą"? Pytanie to pozostawiam otwarte jako pretekst do dalszego namysłu nad „laboratorium humanistycznym”, ale chciałbym pokusić się o sformułowanie jednego wniosku, który wydaje mi się istotny. Otóż kłopot akademickiej humanistyki z laboratorium wydaje się mieć podstawy historyczne i instytucjonalne, wynikające z tego, że przez lata praca laboratoryjna humanistów pozostawała ślepą plamką w oku akademii. Wykonywana o wiele częściej, niż wskazywałaby liczba istniejących laboratoriów humanistycznych, była przez lata częścią zawodowego warsztatu czy też pozaakademickich kompetencji badaczy, kształtowanych pod wpływem ich prywatnych pasji i doświadczeń. Być może zatem wciąż czeka na nas osobna, a zapewne także osobliwa, monografia etnograficzna prywatnych laboratoryjnych praktyk humanistów - owego sekretnego życia materialnością prowadzonego przez obserwatorów ze świata idei.

20 Ten aspekt instytucjonalizacji, ufundowanej przez decyzje polityczne i ekonomiczne, laboratoriów dźwiękowych tworzonych w ramach eksperymentalnych studiów radiowych omawia szeroko Georgina Born w książce Rationalizing culture: IRCAM, Boulez, and the institutionalization of the musical avant-garde, University of California Press, Berkeley 1995. się" jest "jak najbardziej realne" i „nie wytwarza niczego poza sobą". G. Deleuze, F. Guattari Tysiq̨c plateau, red. J. Bednarek, Fundacja Bęc Zmiana, Warszawa 2015, s. 288. 


\section{Abstract}

\section{Dariusz Brzostek}

ADAM MICKIEWICZ UNIVERSITY (POZNAŃ)

The Emergence of the Laboratory: The Humanities and the Materiality of the Tools and Objects of Research

Review: Piotr Marecki, Praktyka i eksperyment: Laboratoryjny model humanistyki [Practice and Experiment: The Laboratory Model of the Humanities], Wydawnictwo Uniwersytetu Jagiellońskiego, Cracow 2019.

\section{Keywords}

laboratory, humanities, practice, experiment, actor-network theory 